\title{
The Montreal Declaration on Free Access to Law (MDFAL) of 2002: A Weak Reed for Global Realization of the Right to Access Legal Information
}

\author{
By Omari Issa Ndamungu \\ $\mathrm{PhD}$ candidate at the Open University of Tanzania, Assistant Lecturer (Laws) at Mzumbe University (Mbeya \\ Campus College), P.O. Box 6559 Mbeya
}

\begin{abstract}
The beginning of 2000 witnessed emergence of global campaigns for realization of the right to access legal information. The campaigns were initiated by activists of the Free Access to Law Movements (FALM). In order to make the campaigns more formal the FALM drafted the Montreal Declaration on Free Access to Law (MDFAL) of 2002. Although the principles of the MDFAL of 2002 are good it suffers from a sort of 'birth defect' problems, one of which being the fact that the MDFAL of 2002 is not in the realm of international law. One can only assume that if the MDFAL of 2002 was in the realm of international law, realization of its principles would be more realistic than it is now. The aim of this article is to provide a critique of the MDFAL of 2002 which makes realization of the right to access legal information illusive.
\end{abstract}

Keywords: Free Access to Legal Information, Legal information, Legal information institutes, Montreal Declaration on Free Access to Law

DOI: $10.7176 / \mathrm{JLPG} / 105-09$

Publication date: January $31^{\text {st }} 2021$

\subsection{Introduction}

Legal information is on the march as the countries now have constitutional provisions on the right to access information, the Right to Information (RTI) laws and the Legal Information Institutes (LIIs). The LIIs and the RTI give the right to access legal information a legal status which is to be enforceable. Again the Free Access to Law Movement (FALM) and the LIIs has ruled that access to legal information is important. ${ }^{1}$ The LIIs around the world are taking up the challenge of opening up to the public and the recognition that enlightenment ideas of a public right to access public legal information is a sine qua non of $21^{\text {st }}$ century administration of justice. Movements for realization of the right to access legal information reached a crescendo after the drafting and accepting by the LIIs of the Montreal Declaration on Free Access to Law (MDFAL) of 2002. The MDFAL of 2002 is predicated on the principles of promoting online publication of all public legal information available in a country for easy access by the public. To date the MDFAL of 2002 has 73 LIIs as participating non-governmental institutions actively involved in campaigns for access to legal information. There is a vibrant world, regional and national LIIs promoting online publication of legal information for public to access legal information.

Yet, in spite of all this progress, access to legal information in most of the countries has faced legal challenges on its enforcement. This means despite the centrality of the MDFAL of 2002 the right to access legal information faces claims of irrelevance and dictions of demise. This is caused by inter alia, lack of specific law covering specifically the right to access legal information at international level, regional level and in most of the countries, save for the United States of America (USA). This article has found out that the USA has specific law on the right to access legal information, which is the Uniform Electronic Legal Materials Act (UELMA) of 2011. The UELMA of 2011 has significant provision which essentially cover most of the principles of the MDFAL of $2002 .^{2}$ The UELMA of 2011 is therefore one of the best example of legislation on the right to access legal information at national level.

Absence of international, regional and national laws which specifically cover enforcement of the right to access legal information no wonder creates difficult in enforcement of the right. This is because realization of the right to access legal information depends on mercy of the Government to take purposive measure to ensure that the right to access legal information becomes a reality.

At international level realization of the right to access legal information is hindered by the fact that the MDFAL of 2002 is not binding as it is not recognized in the international law realm. At national level only the USA has specific law for the access to legal information which is the UELMA of 2011. In the rest of the countries in the world, enforcement of the right to access legal information is through normal RTI laws of the respective country. This makes enforcement of the principles of the MDFAL of 2002 illusive.

The aim of this article therefore is to provide a critique of the MDFAL of 2002 as a global document in

\footnotetext{
${ }^{1}$ Greenleaf, G, (2010), The Global Development of Free Access to Legal Information in Paliwala, A, (Ed), A History of Legal Informatics, LEFIS Series, University of Zaragoza Press, p 51

${ }^{2}$ Section 8(1) of the UELMA of 2011
} 
struggles for realization of the right to access legal information. After the critique this article argues that it is difficult to reach any definitive global conclusion given the role of the MDFAL of 2002 in realization of the right to access legal information.

\subsection{Methodology}

This article is a result of doctrinal legal research. This means in collection of materials for this article the author used doctrinal research methodology, which involved primary and secondary data collection. In primary data collection the author read various legal instruments on the right to access information in general and the right to access legal information in particular. Since the article is pure doctrinal the author therefore made use of various legal instruments in legal information and the right to access information. In this regard the Universal Declaration on Human Rights (UDHR) of 1948, the International Covenant on Peoples' Rights (ICCPR) of 1966, the MDFAL of 2002, UELMA of 2011, the Nigerian Freedom of Information Act (NFIA) of 2011, the Right to Information Act (RIA) of 2009, the Promotion of Access to Information Act (PAIA) of 2000 and the Access to Information Act (AIA) of 2016 were examined to get legal position of the right to access legal information. As a secondary data method the author read various text books, monographs, articles, seminar papers and other relevant writings on the right to access information generally and the right to access legal information in particular for background information on the right to information.

The paper is divided into five parts. Part one contains an introduction which outlines about the article. Part two analyzes overview of information generally by giving meaning of information, the right to information and scope of the right to access information. Part three is on overview of legal information. Here, the article provides the meaning of legal information, global perspective on legal information right and justification for the right to access legal information. This part portrays one thing, that the right to access legal information is imperative for smooth administration of justice. In Part four, the article gives critiques on the MDFAL of 2002 as a global document for enforcement of the right to access legal information. The article submits that despite being an advanced document on the right to access legal information the MDFAL of 2002 is in dictions of demise. In critiquing the MDFAL of 2002 the article therefore point out its legal and factual weakness which make it irrelevant document to achieve the objectives of the FALM. In part five the article provides conclusion and recommendations. After explaining position of the MDFAL of 2002 in struggles for realization of the right to access legal information, the article gives summary of the arguments and a way forward.

\subsection{Overview of Information}

Information is very important concept today in the world. It has been argued that information is a basic condition for economic developments, together with capital, labour and raw materials. ${ }^{1}$ There are various ways in which information is generated, imparted and obtained by its users. Users of information, on the other hand, need information for various activities and purposes. Some need information for studies, others need information for research, whereas others need it for problem solving. Yet, there are other users who need information for entertainment and while others need information just for knowledge. Users of information acquire various kinds of information depending, of course, on the purposes for which information is needed. Research shows that the most wanted information is that which is good, useful and which has value. ${ }^{2}$ Information will be good, useful and valuable if it is timely accessed, accurate, complete, reliable and targeted to the right users.

Information is to be communicated in time with right level of details and is communicated by appropriate channels, the channels which are understandable to users. This means information must reach the users within reasonable time. Delays in imparting information destroy the value of information since if it is imparted late the information may be useless to the user by the time the user receive it. The European Court of Human Rights (ECHR) has once noted that information 'is a perishable commodity and to delay its publication even for a short period may well deprive it of all value and interest. ${ }^{3}$ Timely communication of information includes the fact that information is current and up to date. Information has value as it brings clarity and creates an intelligent human response in the mind. It is valuable since it can affect behaviours, decision or outcome of the users thereof. Good information means information is accurate, free from mistakes and has clarity. It is information which is accurate and is free from bias. Information is useful if it answers all the questions relevant to that information. ${ }^{4}$ Useful information then is that information which is capable of helping users in their desired activities. The RTI laws require public institutions to publish relevant and useful information for the public to access and use. ${ }^{5}$ Information

\footnotetext{
${ }^{1}$ Arrow, K. J., (1979), The Economics of Information, in M. L., Dertouzo and J. Moses, (Eds), The Computer Age: A Twenty-Year View, MA: MIT Press, Cambridge, pp. 306-317

${ }^{2}$ Ibid, p. 310

${ }^{3}$ Darbishire, H., (2011), Proactive Transparency: the Future of the Right to Information? A Review of Standards, Challenges and Opportunities, World Bank Institute, Governance Working paper Series, Access to Information Programme, Washington DC, p. 16

${ }^{4}$ Martin, M., (2014), “Right to Access to Information Law: Importance and Implementations," Transparency International, Michelsen Institute, No. 10 , p. 1

${ }^{5}$ Martini, M., (2014), Right to Information Law: Impact and Implementation, Transparency International, No. 10, p. 2
} 
then, in order to be described as good, must be relevant to the context and to the subject for which it is needed.

\subsection{Meaning of Information}

There are various definitions of concept information which are drawn from various sources. This is so because the concept information is used differently in various contexts by various experts. Thus, several experts like Belkins, (2010), Bell, (2000), Brokes, (1980), Losee, (1997), Isazadeh, (2004) and Debons, (1983) have defined information as used in the discipline of information science while Aiyar, (2005), Singh (2005) and Majumdar (2005) have defined it in humanities and social science discipline. The definitions of Belkins (2010), Bell (2000), Brokes (1980) and Debons (1983) however, are not discussed in this article as those definitions have different purposes from that of this article. These scientists define information depending on the role it is given in a theory. ${ }^{1}$ This can be proved by the way Isazadeh (2004) defines the concept information by giving formula and variables. ${ }^{2}$ It is therefore submitted that such definition surely does not fit to the nature of this article.

Information consists of data that has been organized to help answering questions and to solve problems. ${ }^{3}$ It is a product of data processing and it is data that has been given meaning by way of relational connection. Information is knowledge that one derives from facts placed in the right context with the purpose of reducing uncertainty. Aiyar (2005) defines information to mean data, text, images, sounds, voice, codes, computer programmes, software and data bases or micro film or computer generated micro fiche. ${ }^{4}$ Generally, information is any material in any form relating to the administrations, operations or decisions of a public authority. Thus, information is instruction or knowledge derived from external source concerning facts, particulars or as to law relating to a matter bearing on assessment. ${ }^{5}$ These definitions fit the theme of this article.

That aside, the African Commission on Human and Peoples' Rights Guidelines has come up with a clear definition of the term information. According to the African Commission on Human and Peoples' Rights Guidelines, information is defined as follows:

"Information includes any original or copy of documentary material irrespective of its physical characteristics, such as records, correspondence, fact, opinion, advice, advertisement, memorandum, diagram, photograph, audio or visual record, and any other tangible or intangible material, regardless of the forum or medium in which it is held, in the possession or under the control of the information holder..."

This definition does not have similarity, even a slightest one as the ones given by the scientists above. The definition given by the African Commission on Human and Peoples' Rights Guidelines has long stressed the social, as well as the physical dimensions of information and it emphasizes on the priority to be given to the contents rather than the forum or medium in which information is stored. It further provides controlling power of the state, as the most holder of information needed by the people, in ensuring that information is available the moment it is requested. The above meaning of the concept information is adequate for attempt to add more things in defining the concept may cause more controversy in understanding the concept itself. That notwithstanding, this article submits that information is very important to human developments.

In everyday English information is defined as knowledge which is communicated from one source to recipient thereof. ${ }^{7}$ On this basis knowledge and its communication are basic phenomena of every human society. This then makes modern society to be characterized as information society. Information society is a term of a society in which creation, distribution and imparting of information has become the most significant economic and cultural activity. ${ }^{8}$ It is a society in which information of various forms is becoming important commodity and measurement of prosperity than physical objects. ${ }^{9}$ Information society is a term which describes the form of society being created in the information age based mainly on the increasingly interactive acquisition, storage, processing, transmission, distribution and use of information and knowledge. ${ }^{10}$ This is what modern society is and thus, it qualifies to be described as information society.

\footnotetext{
${ }^{1}$ Bogdan, R.J., (1994), Grounds for Cognition: How Good and Guided Behaviour Shapes the Mind, Hillsdale, p. 53

${ }^{2}$ Isazadeh, A., (2004), Information Society: Concepts and Definitions, Tabriz University, Department of Computer Science, Tabriz, p. 2

${ }_{3}^{3}$ Aiyar, R., (2005), Advanced Law Lexicon, the Encyclopedic Law Dictionary with Legal Maxim, Latin Terms and Words and Phrases, Vol 2, D I, Wadhwa and Compnay Nagpur, New Delhi, p. 2334

${ }^{4}$ Ibid, p. 2337

${ }^{5}$ Singh, L.P. and Majumdar, P.K., (2005), Judicial Dictionary, Orient Publishing Company, New Delhi, p. 771

${ }^{6}$ Guideline 1 of the Guidelines on Access to Information and Elections in Africa, (2017), the African Commission on Human and peoples' Rights Guidelines, Addis Ababa,

${ }^{7}$ Capurro, R., (2003), “The Concept of Information,” Annual Review of Information Science and Technology, Vol. 37, Hochschule der Medien, Cronin, p. 343

${ }^{8}$ Arora, R., (1993), Information Source: Concepts and Need for Information, Library Information Science, p. 3

${ }^{9}$ Lloyd, J.T., (2000), Information Technology Law, $3^{\text {rd }}$ Edition, Butterworth, London, 2000, p. 11 as found in Mambi, A.J., (2010), ICT Law Book: A Sourcebook for Information and Communication Technologies Law in Tanzania and East Africa, Mkuki and Nyota, Dar es Salaam, p. 6

${ }^{10}$ Aiyar, R., op cit, p. 2337
} 


\subsection{The Right to Information}

International conventions which are binding upon states which have ratified them, serve as paramount international source of the right to information generally. These conventions in summary provide that persons have the right to freedom of expression, the right which includes freedom to seek, receive and impart information and ideas of all kinds, regardless of frontiers. ${ }^{1}$ These provisions are said to be broad in construction and, although expressly they do not mention the right to access information the right to freedom of express has been accepted to include the right to access information. This then is the beginning of the international, regional and local efforts to formulate the right to access information or right to information as human right issue. This is proved by the efforts which were taken by the United Nations (UN) to advocate for access to information. For example Article 10 of the United Nations Convention Against Corruption (UNCAC) of 2003 which was adopted on $29^{\text {th }}$ September 2003 contains a formulation of the right to information. Article 10 of the UNCAC of 2003 provides that;

"Taking into account the need to combat corruption, each State Party shall, in accordance with the fundamental principles of its domestic law, take such measures as may be necessary to enhance transparency in its public administration, including with regard to its organization, functioning and decision making process, where appropriate. Such measures may include, inter alia;

(a). Adopting procedures or regulations allowing members of the general public to obtain, where appropriate, information on the organization, functioning and decision-making process of its public administration, with due regard for the protection of privacy and personal data, on decisions and legal acts that concern members of the public;

(b). Simplifying administrative procedures, where appropriate, in order to facilitate public access to the competent decision-making authorities; and

(c). Publishing information, which may be include periodic reports on the risks of corruption in its publications."

In 1993 the UN formed the Special Rapporteur on protection of cultural and intellectual property of indigenous peoples. ${ }^{2}$ The Rapporteur was mandated to study cultural and intellectual property rights of the indigenous and to provide recommendations on the best way for realization of such protection. In March 2017 the United Nations Human Rights Council extended the mandate of the Special Rapporteur from what it has previously to new directive related to right to information. ${ }^{3}$ The new mandate empowers the Special Rapporteur 'to gather all relevant information, whether it may occur, relating to violation of the right to freedom of opinions and expression, discrimination against threats or use of violence, harassment, persecution or intimidation directed to a persons seeking to exercise or to promote the exercise of the right to freedom of opinion and expression including, as a matter of high priority, against journalists or other professionals in the field of information.' These two international outlook and acuity developed the basis for implementing movements and legislation which have implications for the observance of the right to access information.

Generally, up to this point the article reveals the existence of deliberate efforts on the part of international institutions to give a considerable attention to human rights. Human rights such as the right of access to information are regarded as unduly political and not within the technical mandate of the Universal Declaration on Human Rights (UDHR) of 1948, the international Covenant on Civil and Peoples' Rights (ICCPR) of 1966 and the African Charter on Human Rights (ACHR) of 1981. Nonetheless, the article reveals that, the right of access to information as developed by the international instruments does not mean the right to access any information which is held by the Government. It is the right to access information, the information which can be accessed subject to certain restrictions as may be provided by laws of respective countries. ${ }^{4}$ That has consequently led to the reformation by the international, regional and national instruments of the right of access to information which focuses on success and obstacles in the access to information. Though the above position shows advancement in struggles for the right to access information, much in the world remains a number of challenges, including countries without the RTI legislation, patchy implementation of the RTI legislation and, worst still, some countries which have continual resistance to the RTI movements. That is, in implementation of the RTI legislative movements and enforcement, the states have a role to play in levelling the playing ground with respect to disclosure and access to information, including developing the RTI policies, plans and strategies. However, factors such as lack of resources to finance the RTI legislative movements and campaigns are beyond the control of the state.

\subsection{The Scope of Access to Information}

The right to access information is the right of everyone to know, to have access to the information he needs to

\footnotetext{
${ }^{1}$ Article 19 of the UDHR of 1948, Article 19 of the ICCPR of 1966, Article 13 of the ACHR of 1981 and Article 9 of the ACHPR of 1981

${ }^{2}$ See the Commission on Human Rights-Sub-Commission on Prevention of Discrimination and Protection of Minorities, Forty Sixth Session, Item 14 of Provisional Agenda, Distr. General, E/CN.4/Sub.2/1993/28, 28 $8^{\text {th }}$ July 1993

${ }^{3}$ The United Nations Council (HRC) of Human Rights, HRC Resolution No. 34/18 of March 2017

${ }^{4}$ See for example Article 19(3) of the ICCPR of 1966
} 
make use of. ${ }^{1}$ The practical application of the right to access information underpins two distinctive principles which are publicity of acts and transparency of public administration.

The right to information does not exist in isolation but it is understood as a member of larger group of civil and political rights, a component part of the fundamental right to freedom of expression and opinion, which requires the Government to refrain from interfering with free flow of information and ideas. ${ }^{2}$ In other words the right to information is also intricately to and necessary for the protection of all other human rights. This right is now receiving growing attention and treatment in international and regional legal instruments. The understanding of the rights to provide access to information, as well as to refrain from interfering with communication of information necessary to a citizen's ability to make choice are key components of freedom of expression and opinion. It is to be born in mind that all information which is held by Government and her agencies is in principle public information. As such information held by the Government may only be withheld if there is legitimate reason for not disclosing it. Grounds for withholding information should be clearly and specifically established by law with the goal of protecting legitimate aims. This article submits that in order to facilitate access to information processes for requesting information should be the least complicated and most efficient possible and the provision of information should be quick and complete.

Noteworthy, the reference in Article 19(3) of the ICCPR of 1966 to freedom of opinion and expression is not confined to the right to express one's opinion without legal restraint alone. On the contrary the drafting history and the express wording of Article 19(3) of the ICCPR of 1966 acknowledges that the freedom of expression embraces a wide range of social economic factors that promotes conditions in which people can seek, receive and impart information and ideas of all kinds and extends to the underlying determinants of 'freedom of expression and opinion' such as special duties and responsibilities for respect of the rights or reputation of others, protection of national security, public order and protection of public health or morals. ${ }^{3}$ This article submits that freedom of expression and opinion includes and extends to effective access to legal information. Thus, it follows that the right to access information contains both freedoms and entitlements. The freedoms include the right to acquire relevant information as well as the right to be free to impact the acquired information free from censorship, restrain or legal penalty. ${ }^{4}$

Explaining the scope of freedom of opinion and expression after analysing international treaties and other elements of human rights discourse in particular the reporting procedures of the ICCPR of 1966 stated that;

"Freedom of opinion and expression constitutes one of the essential foundations of a

democratic society, one of the basic conditions for its progress and for each individual's self

fulfilment." 5

Accordingly it is viewed that the UN approaches of defining the scope of the right to access information is appropriate starting from political and legal set up in that the entitlements under the right to expression and opinion are such that every state, no matter at what stage of development, may reasonably be expected to comply.

\subsection{Overview of Legal Information}

Information is of great important in every profession and legal information is no exception. This is so because law is enduring and changes from time to time. This requires judges, lawyers and general public to always be aware of all the changes in primary legal information. Accessing legal information is thus very important to judges, lawyers and the public at large. It is important to judges because it enables them to rightly apply laws in deciding various cases and administer justice according to all prevailing legal rules in the country. It is important to lawyers because it enables them to provide accurate legal advice to clients on proper laws of the country according to the need of the client. It is likewise important to the general public because knowledge of the law prevented them to be victim of law. This is so because there is a legal maxim that ignorantia juris non execusat (ignorance of the law excuses no one). Besides, decision of current cases depends on interpretation and application of statutes and case laws. Therefore, judges, lawyers and public have to access legal information for proper administration of justice. Relevant legal information then helps to create confidence to judges, lawyers and public at large in delivery of justice processes. To be able to apply relevant legal information judges, lawyers and the public must access legal information available. In variety of ways, legal information may be made accessible in two major ways: accessing hardcopy legal information and accessing softcopy legal information. Below is a discussion of legal information in perspective.

\footnotetext{
${ }^{1}$ Borne, R., (2007), Access to Information: An Instrumental Right for Empowerment, Yale Law School, London, p. 33

${ }^{2}$ See Leader vs. Sweden, Judgment of $26^{\text {th }}$ March 1987, Series A, No. 116, Para 74. In this case the European Court of Human Rights ruled that the right to receive information 'basically prohibits a government from restricting a person from receiving information that others may wish or may be willing to impart to him.'

${ }^{3}$ Sturmer, M., (2008), The Media History in Tanzania, Ndanda Mission Press, Mtwara, p. 165

${ }^{4}$ Omar, J., (1990), Regulating Broadcasting in Tanzania, A Thesis die Diploma in Journalism, Tanzania School of Journalism, Dar es Salaam, 26

${ }^{5}$ The UN, (2011), International Committee on People's Rights, General Comment No. 34, Article 19 Freedom of Opinion and Expression, Human Rights Committee, Geneva, p. 4
} 


\subsection{Meaning of Legal Information}

In any area of study consideration of the history or origin of the subject matter is necessary for an appreciation of the background, growth and future of the subject matter. ${ }^{1}$ Legal information is no exception. But before trying to give its historical perspective it is apposite to provide the meaning of the concept legal information.

According to Singh (2012) legal information or public legal information is any legal information produced by public bodies that have a duty to produce law and make it public. It includes primary source of law, such as legislation, case law and treaties as well as various secondary public sources, such as reports on preparatory works and law reform, and resulting from boards of inquiry. It also includes legal documents created as a result of public funding. ${ }^{2}$ From this definition it means legal information is any material which contains law the same being a document or other source.

While that is the definition obtained from literature the LII of the world meeting in Montreal declared that;

(a). Legal information from countries and international institutions is part of the common heritage of human. Maximize access to this information promotes justice and the rule of law, Public legal information is digital common property and should be accessible to all on a non profit basis and free of charge,

(c). Organizations such as legal information institutes have the right to publish legal information and the government bodies that create or control that information should provide access to it so that it can be published by other parties. ${ }^{3}$

According to the MDFAL of 2002 legal information like case law, legislation and other Government documents form a greater role in awareness of duties and responsibilities to the citizens. ${ }^{4}$ If law is accessible to all there is comparatively less chance to being its victim. Innovation of communication technology brought a big impact in access and communication of information, including legal information.

\subsection{Justification for Access to Legal Information}

The above legal position presents significance of information. It is therefore the responsibility of the Governments in various countries to create atmosphere that fosters access to information to ensure adequate disclosure and dissemination of information in a manner that offers necessary facilities and eliminate existing obstacles to its attainment. Without access to information to accurate, credible and reliable legal information especially recent legislation and case law judges will not be able to correctly and precisely decide cases according to law and long established precedents. The importance of receiving and accessing legal information in administration of justice is therefore beyond reprove.

A cardinal principle at the heart of the right to information is that of active proactive disclosure. The principle of proactive disclosure requires that those who hold information of public interest must routinely provide such information in easily accessible ways and they must consider the needs of intended users. ${ }^{5}$ Proactive disclosure of legal information is thus a tool for access to justice and administration of justice.

The right to access legal information is not only important in order to be able to enforce legal rights it is also useful to know developments of administration of justice in a given country. Moreover, among the varied constitutional rights freedom of information imposes the most clear cut obligations on the Governments. ${ }^{6}$ Article 19(2) of the ICCPR of 1966 requires Governments to respect and ensure the right to access information. This provision puts obligation to the Governments of the state parties to respect the right by not violating it indirectly through legislation, policies, judicial decisions or actions of its official or agents. ${ }^{7}$ In order to fulfil the requirement of Article 19(2) of the ICCPR of 1966 the Governments must take direct and affirmative action possible to protect and respect the right to access information by preventing its violation. The Governments also must fulfil the right to access information by enacting legislative policies or judicial precedents. ${ }^{8}$ Therefore, the Governments must take steps to ensure that individuals are able and free to access legal information like unreported precedents, legislation and other relevant legal information. Increasingly, the Governments must also fulfil their obligation by providing legal information in circumstances of public interests, particularly in relation to and concerning legal information.

The interpretation of the right to legal information, access to justice and administration of justice can be highly instructive of the Government's attitude towards facilitation of access to legal information. States should allow individuals access to legal information that have importance on their right to access justice and delivery of justice,

\footnotetext{
${ }^{1}$ Akintunde, S, E, (2017), A Brief Overview of Legal Informatics, Institute of Legal Informatics, Hanover, p. 2

${ }^{2}$ Singh, R, et al, (Eds), (2012), Access to Legal Information and Research in Digital Age, National Law University Press, Delhi, p. 29

${ }^{3}$ The Principles in the MDFAL of 2002, p. 1

${ }^{4}$ Singh, R, et al, (Eds), p. 29

${ }^{5}$ The AfCHPR, Guidelines on Access to Information and Elections in Africa, AU, 2017, p. 5

${ }^{6}$ Ibid

${ }^{7}$ Eide, A., (1989), “Realization of Social and Economic Rights and the Minimum Threshold Approach,” Human Rights Law Journal, p. 35

${ }^{8}$ Alston, P and Quinn, G., (2007), "The Nature and Scope of State Parties' Obligations in the International Covenant on ESCR, Human Rights

Quarterly Law Journal, p 37
} 
which in turn will allow them to exercise other legal rights. This article submits that legal information is important for learning about the exercise of legal right, access to justice and administration of justice system. Individuals have to access legal information so that they know about justice delivery system, legal rights and procedure and requirements to access justice. Individuals should also be aware of the legal position of the judges on a particular legal issue, something which creates uniformity and certainty of judicial decisions on one particular issue throughout the country. On the contrary the failure to access legal information constitutes a violation of obligation of states which they agreed when ratifying, acceding or succeeding the UDHR of 1948, the ICCPR of 1966 and the ACHPR of 1981. The UN Committee of Human Rights has stated for example in its General Comment No. 24, Paragraph 54 and in relation to the right to access legal information for a person to be able to take legal remedies against any judicial or administrative decisions. Moreover, states have the obligation to submit reports on measures that they have taken and progress made in achieving obligation assumed in the international laws.

Struggles for access to legal information have short history although its history can be traced as way back as Confucius and Socrates eras. ${ }^{1}$ The first person to initiate or put struggles for access to legal information is believed to be John Horty. But credit for transformation of the struggles goes to Cornell Legal Information Institute (CornLII) which was founded by Tom Bruce. ${ }^{2}$ The CornLII is the founder of free access legal information retrieval system. It was after foundation of the CornLII that movements towards formation of free access to law institutes in the world began. First step was formation of the British and Irish Legal Education Association (BILEA) in 1985. The BILEA was formed in order to promote collaboration in all aspects to legal informatics and information law. ${ }^{3}$ After formation of the BILEA nearly all law schools in Britain and Ireland which supported access to law movements joined the BILEA. ${ }^{4}$ Expansion of the BILEA led to the formation of the Law Technology Center (LTC). This spawned law courseware consortium which inter alia developed a number of e-journal including Journal of Information Law and Technology (JILT). ${ }^{5}$

The second step towards legal information movements was formation of two prominent organizations on legal information movements. These are the International Conference on Legal Knowledge and Information System (JURIX) and the International Association for Artificial Intelligence and Law (IAAIL). ${ }^{6}$ These are traditional scientific conferences whose main activity is conference organization and publication of journals. ${ }^{7}$ As a result of these the Legal Framework for Information Society (LEFIS) was formed. The LEFIS has brought together over 90 law schools throughout Europe with growing worldwide links with legal practitioners and the Information Technology (IT) professionals. The IT professionals are equally important in legal information movements because they are the tools for information system as the same are used for storing, communication, dissemination and retrieval of information. This is so because the public can use computers to access text of statutes or case laws. It means by using computers statutes can be communicated from parliament house after being enacted to the court houses and to the people.

The LEFIS then organized a number of conferences, and workshops and it published a series of journals on information and access to legal information. It also promoted a wide range of collaborative projects, and the most common collaborative especially on legal information is the Legal Information Institutes (LII). ${ }^{8}$ The LII as one of a collaborative project of the LEFIS is very significant to this article.

The LII refers to providers of legal information that is independent of the Government, and provides free access on a non profit basis to multiple sources of essential legal information. The LII is a group of projects that provide free online access to public legal information, defined in the Montreal Declaration on Free Access to Law (MDFAL) of 2002. ${ }^{9}$ The LII represents a reaction to a retrieve and protective attitude towards making legal materials available to lawyers. ${ }^{10}$ Legal information which the LII offers to lawyers is freely available and without being curtailed by copyright laws. ${ }^{11}$ The formation of the LII led to the formation of World Legal Information Institutes (the WorldLII).

The WorldLII is an umbrella organization of all modern LII in the world. As Greenleaf (2013) and Bing (2000) indicate the LII movements have been the basis for major worldwide transformation in access to justice for lawyers as well as for general public. ${ }^{12}$ This trend and movements towards realization of access to legal information signifies the importance of access to legal information. Susskind (2019) suggests, and this article joins

\footnotetext{
${ }^{1}$ Paliwala, A., (Ed), (2010), “A History of Legal Informatics,” LEFIS Series 9, Prensas Universitarias de Zaragoza, Zaragoza, p. 14

Ibid

${ }^{3}$ Ibid p. 17

${ }^{4}$ Ibid

${ }^{5}$ Ibid

${ }^{6}$ Ibid

${ }^{7}$ Ibid

${ }^{8}$ Paliwala, A., (Ed), (2010), A History of Legal Informatics, LEFIS Series 9, Prensas Universitarias de Zaragoza, Zaragoza, p. 17

${ }^{9}$ Garvin, P,(Ed), Government Information Management in the Twenty-First Century, Butterworth, London, 2010, p. 213

${ }^{10}$ Kondos, G.R., (1973), 'Introduction to JURIS,' A Paper Presented in Abidjan World Conference on World Peace Through Law, Abidjan, p. 47

${ }^{11}$ This is permitted by Article 2(4) of the Berne Copyright Convention of 1888

${ }^{12}$ Paliwala, A., op cit, p. 43
} 
hands with him, that avoiding access to legal information is akin to burying our heads in the sand. This then serves as an explanation as to why lawyers from the very beginning gave preference to a system which grant access to legal information. That is why nowadays there are websites in almost every country which provide legal information. It should be noted here that although lawyers are not avant gardists text retrieval was actually developed by lawyers and for lawyers, due to the need to access legal information. ${ }^{1}$ It is to be noted that among the efforts towards text retrieval programmes was made by the Norwegian Research Center for Computers and Law (NRCCL), faculty of law of university of Oslo. ${ }^{2}$ It is therefore fair to argue that uploading and downloading systems of materials on the internet which are very common in the world today are fruits of effort of the lawyers.

Taken together the LII are the most coordinated and among the largest providers of access to legal information, but are not backed up by any legal instrument except mutual understanding and consent among themselves. ${ }^{3}$ More particularly from 2000 the LIIs expanded and as a result there were various LIIs found in various countries. ${ }^{4}$ As by April 2013 there were 50 members of the LIIs. This expansion of the LII worldwide necessitated to the formation of the FALM in 2002. A desire to have access to law via the internet has been principal means by which the FALM and the LIIs were established.

To put this desire into effect several conferences were convened, the first one being hosted by Australia LII (AustLII) in $1997 . .^{5}$ It came as a result of associations of the group of the LIIs which made initial attempts to establish collaboration and organization to further access to law globally. The first sustained attempt to build some form of international network took place at Cornell University in July $2000 .^{6}$ In the workshop participants from the USA, Canada, Australia, Britain and the South Africa attended. ${ }^{7}$ During deliberation the expression WorldLII was firstly used, which had connotation of collaborative the LIIs worldwide. The workshop of 2000 resulted into the FALM Conference of Montreal of $2002 .{ }^{8}$

The FALM Conference of Montreal of 2002 adopted the MDFAL of 2002, popularly known as the Montreal Declaration on Free Access to Law (MDFAL) of 2002. ${ }^{9}$ The MDFAL of 2002 defines legal information, creates obligations to the member states to support republication of legal information and calls up for formation and operation of the LII in individual countries, among other things. As for definition of legal information the MDFAL of 2002 defines legal information by providing that;

“... legal information means legal information produced by public bodies that have a duty to

produce law and make it public. It includes primary sources of law, such as legislation, case

law and treaties ..."

Membership to the MDFAL of 2002 is by invitation and consensus of the present members. ${ }^{10}$ New member therefore is admitted to it if is nominated by current member and other members reach a consensus to admit the invited new member. Membership criteria are not fixed but involves adherence to and support of the MDFAL of 2002 and activities similar to but not necessarily identical with those of the LII. ${ }^{11}$ Membership of the MDFAL of 2002 has ever since expanding beyond the initial members to include other national the LIIs from North America, South America, Europe, Asia and Africa. ${ }^{12}$

All these were done emphasize being facilitation of public access to law and to make law available for the people. ${ }^{13}$ It is important for the people to know the law because ingorantia juris non execusat, which means ignorance of the law, excuses no one. Consequently, access to legal information, such as legislation and unreported case laws becomes an essential component of any modern legal system, irrespective of the fact that the MDFAL of 2002 is unenforceable. ${ }^{14}$ Thus, the wide spread distribution and accessibility of the legislation and case laws contributes greatly to the transparency, openness and certainty of judicial decisions, something which is essential to the social functioning of administration of justice system. In fact the possibility of identifying legal information like legislation and unreported case laws contributes to ensuring the integrity of any judicial institution. ${ }^{15}$ It is

\footnotetext{
${ }^{1}$ Bing, J and Trygve, H, (1975), Legal Decisions and Information Systems, Scandinavian University Press, Oslo, 76

${ }^{2}$ Ibid, p. 76

${ }^{3}$ Greenleaf, G., (2010), “The Global Development of Free Access to Legal Informatics," The European Journal of Law and Technology, Vol.

I, Issue 1, Zaragoza University Press, Zaragoza, p. 44

${ }^{4}$ Ibid

${ }^{5}$ Danner, R.A., (2003), The IALL International Handbook of Legal Information Management, p. 206

${ }^{6}$ LII Workshop on Emerging Global Public Legal Information Standards, (2000), Cornell University Press, Cornell, p. 21

${ }^{7}$ Greenleaf, G, op cit

${ }^{8}$ Greenleaf, G., (2010), The Global Development of Free Access to Legal Informatics, LEFIS Series, University of Zaragoza Press, Zaragoza, p. 52

${ }_{9}^{9}$ Available at www.worldlii.org.worldlii/declaration, accessed on $25^{\text {th }}$ October 2019

${ }^{10}$ The MDFAL of 2002, Paragraph 1, p. 2

${ }^{11}$ Danner, R.A., (2010), The IALL International Handbook of Legal Information Management, p. 206

${ }^{12}$ Greenleaf, G., op cit, p. 52

${ }^{13}$ Daniel, P., (2019), Open Access to Law in Developing Countries, Online Journal of ICT, Vol. 9, No. 12, 2004, accessed on 11 ${ }^{\text {th }}$ September at 1645 hours

${ }^{14}$ Ndamungu, O.I., (2020),Legal and Policy Approaches Toward Realization of the Right to Access Legal Information, International Journal of Research of Sharia, Muamalat and Islam, Vol.2, No. 5, p. 10

${ }^{15}$ Greenleaf, G., op cit
} 
therefore important to have a sound system of free and open access to statutory materials and courts' decisions. In France, Canada and Australia for example, basic legal texts are accessible to anyone. ${ }^{1}$ In the United States of America there is a specific law which ensures the access to legal information. This is known as the UELMA of 2011. It means in these countries there is access to legal information. Such open access to law, however, has not yet been implemented in majority of developing countries, where sometimes even accessing basic legislative text is difficulty. ${ }^{2}$ In such countries then the right to access legal information is difficult something which jeopardize smooth administration of justice.

\subsection{International Instrument on Access to Legal Information}

The MDFAL of 2002 is a global document on the right to access legal information which was drafted in Montreal in 2002 by the LIIs from seven countries. Its major aim is to complement and reinforce the objectives of the FALM in the world. The MDFAL of 2002 was drafted without existence of any formal international legal instrument on the right to access legal information. Thus, the MDFAL of 2002 was drafted pursuant to mutual understanding of the LIIs from seven countries for the purpose of putting formal struggles for realization of legal information globally. The seven countries which participated in drafting of the MDFAL of 2002 are USA, Britain, Canada, Sweden, Finland, Norway and France. As by 2020, 73 LIIs have subscribed to the MDFAL of 2002, recognizing the competence of the FALM to enforce the right to access legal information in the respective countries. Expansion of the subscribers to the MDFAL of 2002 no wonder signifies the importance of the right to access legal information and thus, making the MDFAL of 2002 very important document. Howbeit, despite its significance this article argues that it is impossible to fully realize the right to access legal information through the MDFAL of 2002. This is partly attributed by the birth defects of the MDFAL of 2002 itself. Here under are the critiques of the MDFAL of 2002 as a document which was drafted for the purpose of global enforcement of the right to access legal information.

\subsection{Critiques of the MDFAL of 2002}

Freedom to seek and receive information is recognized as basic human rights by Article 19 of the UDHR of 1948 and Article 19 of the ICCPR of 1966. The right to receive information include as well the right to receive public legal information as it is provided by the MDFAL of 2002. This is because legal information is 'information' within the meaning of Article 19 of the UDHR of 1948 and Article 19 of the ICCPR of 1966. Again, people of countries throughout the world should be able readily to access law that governs them. ${ }^{3}$ Providing such access is a responsibility of the Government and is necessary for proper administration of justice. ${ }^{4}$ Thus, it is the duty of the Government to collect and provide access to official version of legal information, such as legislation and case laws. It is the duty also of the Government to preserve legal information for future uses. ${ }^{5}$ Howbeit, legally and from the right to information perspective there is no obligation to collect information for it to be accessible by the public.

In the digital age many Governments provide online versions of primary sources of law, including statutes and case laws. ${ }^{6}$ This makes it possible for the public to have equitable and continuous access to resources necessary for proper administration of justice, assuming wide and affordable internet service. This part of the article therefore aims at examining weedy points of the MDFAL of 2002, which in turn makes it weak document on which to learn for realization of the right to access legal information.

The MDFAL of 2002 was made by the FALM for the purpose of ensuring that public bodies disclose public legal information. ${ }^{7}$ The MDFAL of 2002 is built on principle that public bodies hold information not for themselves but as custodians of the public good and everyone has a right to access information concerned. ${ }^{8}$ Beneficiaries of the right to access legal information are the people, corporate organization and organs of the Government that are entitled to know the law that regulates their conducts and activities. ${ }^{9}$ Lawyers and general public are also among the beneficiaries thereof since these have the right to know the laws of the country for accessing justice.

Many nations which have adopted the MDFAL of 2002 have enacted legislation to give effect to it. In the USA there is the UELMA of 2011, Nigeria has enacted the Nigerian Freedom of Information Act of 2011, in

\footnotetext{
${ }^{1}$ Daniel, P., (2019), Open Access to Law in Developing Countries, Online Journal of ICT, Vol. 9, No. 12, 2004, accessed on 11 ${ }^{\text {th }}$ September at 1645 hours

${ }^{2}$ Ibid

${ }^{3}$ International Federation of Library Association and Institutions, (2010), IFLA Statement on Government Provision of Public Legal Information in the Digital Age, IFLA, p. 1

${ }^{4}$ Ibid

${ }^{5}$ Ibid

${ }^{6}$ Ibid

${ }^{7}$ This is one of the objectives of the MDFAL of 2002

${ }^{8}$ Mitee, L.E, (2017), The Right of Public Access to Legal Information: A Proposal for Its Universal Recognition as a Human Right, European Journal of Law and Technology, Vol. 8, No.3, p. 1438

${ }^{9}$ Ibid
} 
Ghana there is the Right to Information Act of 2009, the Promotion of Access to Information Act of 2000 is the law for South Africa while in Tanzania there is the Access to Information Act (AIA) of 2016. Almost all of these laws, to some extent, comply with the principles of the MDFAL of 2002. However, history has shown that to give meaning to the right to access information, it must be enforceable and enforced. To meet this mandate, the Governments, international organization and civil society are now focusing on the best means to ensure well constructed and functioning enforcement system. ${ }^{1}$ In most jurisdiction enforcement of access to legal information through the MDFAL of 2002 is challenging due to the fact that it is not enforceable international instrument.

The MDFAL of 2002 is not full-fledged international institution but a mere movement. Efforts were made in 2007 to turn it into association, the effort if succeeded the MDFAL of 2002 would be Free Access to Legal Association (FALA). ${ }^{2}$ But this attempt did not materialize. On the face of it the MDFAL of 2002 which is affiliation of the LIIs is a universal platform with membership coming from all corners of the world (Europe, America, Australia, Asia and Africa). Yet, the MDFAL of 2002 does not have universal declaration status. Again, despite being global, growing and broader grouping since its establishment its membership is still small. As by 2009 members of the MDFAL of 2002 were only $30,{ }^{3}$ out of more than one 180 countries in the world. By 2013 the membership grew to 50 members. ${ }^{4}$ The membership to date being drawn primarily from the LIIs based in academic institutions, although Government based membership is not denied, provided it does not impede others from obtaining public legal information from its sources and publishing it. ${ }^{5}$ In other words, Government body cannot be a member to the MDFAL of 2002 if it provides free access to law in a way that monopolizes publication of that information or supports such monopoly publication. ${ }^{6}$ The key test is whether publication of Government information is allowed. ${ }^{7}$ If the answer to this is in affirmative Government body membership to the MDFAL of 2002 is allowed.

The major aim of the MDFAL of 2002 is provision of assistance by its members to organizations who wish to provide free access to law. ${ }^{8}$ The MDFAL of 2002 therefore intends to provide mutual support to organizations already providing free access to law and who wish now to join the FALM. It is submitted by this article that the MDFAL of 2002 for that purpose is a mere advisory as it does not have legal force internationally or locally save for those countries which have already enacted the RTI laws. This is proved by the fact that the MDFAL of 2002 recognizes 'the primary role of local initiative in free access to law is publishing of their national legal information.'

The MDFAL of 2002 also does not deal with state but rather by institutions called the LIIs in those nations which are the members thereof. This can be viewed from the third and fifth objectives of the MDFAL of 2002 which state that 'all the LIIs must cooperate in order to achieve the goals thereof and to meet at least annually to invite other organizations to join the movement.' As the MDFAL of 2002 puts it, the aim is to cooperate in order to achieve those goals and, in particular, to assist organizations in developing countries to achieve those goals, recognizing the reciprocal advantages that all obtain from access to each other's law. The main activities of the MDFAL of 2002, in the light of those aims, have been sharing of software, technical, expertise and experience on policy questions. ${ }^{9}$ This is contrary from Bing (2003) who argues in favour of state run legal information service that only provides a limited amount of free access to legal information. ${ }^{10}$

Despite some countries, significantly many by size although not by number are the subscribers of the MDFAL of 2002 that does not give them mandate to enforce the MDFAL of 2002 objectives. This means the objectives of the MDFAL of 2002 remain largely unenforceable by the LIIs which are the subscribers to the MDFAL of 2002.

The underlying reason for the MDFAL of 2002 was the desire to form the LII worldwide. One of the fundamental mistakes of the MDFAL of 2002 is that member states who initiated it made it that the struggles for free access to legal information deals exclusively with the rights of individual nation, no reference whatsoever was made in the document to collectiveness. Even state membership thereof was introduced later on in $2007 .{ }^{11}$ Moreover, the MDFAL of 2002 has no force of law as it is a mere declaration with no effect to the nations, even to the countries which have subscribed it. Therefore, it is not possible to incorporate it in the realm of international law. Since the MDFAL of 2002 is not incorporated in the realm of international law majority of the nations in the world do not comply with its principles. Even international organizations like the UN and the AU have practically

\footnotetext{
${ }^{1}$ Neuman, L, (2009), Enforcement Models Content and Context, Access to Information Working Paper Series Washington DC, p. 1

${ }^{2}$ Greenleaf, G., (2010), The Global Development of Free Access to Legal Informatics, LEFIS Series, University of Zaragoza Press, Zaragoza, p. 59

${ }^{3}$ Greenleaf, G., op cit, 2010, p. 44

${ }^{4}$ Greenleaf, G, et al, (2013), “The Meaning of Free Access to Legal Information: A Twenty Year Evolution,” Journal of Open Access to Law, Issue 1, p. 9

${ }^{5}$ Ibid

${ }^{6}$ Ibid

${ }^{7}$ Ibid

${ }^{8}$ Paliwala, A, (2010), History of Legal Informatics, Zaragoza University Press, Zaragoza, p. 23

${ }^{9}$ See statement in the MDFAL of 2002

${ }^{10}$ Bing, J, (2003), The Policies of Legal Information Service: A Perspective of Three Decades, in Bygrave, L, Yules (2003), Oslo: Institutt for rettinformatik/Norwegian Research Center for Computers and Law, p. 37055

${ }^{11}$ Greenleaf, G, op cit, p. 44
} 
not recognized it, the FALM and the LII. ${ }^{1}$

The supposed basic inspiration for drafting the MDFAL of 2002 was the desire to ensure that public legal information is easily accessible by the same being published online by the LIIs. Paliwala (2010) affirms that the integral factor for the drafting of the MDFAL of 2002 was to encourage the LIIs to publish legal information in their respective countries. In support he refers to the statement in the MDFAL of 2002 which provides 'that independent non-profit organization have the right to publish public legal information and the Government bodies that create or control that information should provide access to it so that it can be published' and affirms that this explains why the MDFAL of 2002 has not found support of the UN and the AU. This article reveals that basing on these factors the MDFAL of 2002 has been a total failure.

The drafting of the MDFAL of 2002 did not last long. It was hardly drafted in a day, which was $3^{\text {rd }}$ October 2002 in $4^{\text {th }}$ Law via Internet Conference in Montreal. ${ }^{2}$ The drafting of the MDFAL of 2002 did not involve any Commission of the UN as it is commonly for many international instruments. ${ }^{3}$ With delegates from only seven countries being activists of the FALM participants entertained discussions about all aspects related to free access to and online publication of legal information. ${ }^{4}$ Greenleaf (2013) on his side states that the drafters of the MDFAL of 2002 were aware of how far the FALM had developed and they felt that only a clear statement of separate issues involved free access to law could be dealt with. This means putting online all of the legal right to access law in $21^{\text {st }}$ century had become part of global concern of the activists of the FALM. Thus, nothing resulted from the MDFAL of 2002 regarding obligation of nations to ensure compliance to the MDFAL of 2002 principles. More so no clear authority was given to the UN to supervise implementations and enforceability of the MDFAL of 2002. All of the MDFAL of 2002 conference starting with the declaration itself followed by the two other conferences and continuing with various strategies approved during the following years concentrated on statements of principles, legal concepts or general rules aimed at encouraging online publication of legal information and free access to law.

Two aspects should be taken into consideration. First, even after the FALM became known the nations which had inscribed in their constitutions and other fundamental documents most of the principles of the MDFAL of 2002 failed to respond to it. These countries are idle without taking deliberate steps to make sure principles of the MDFAL of 2002 becomes realizable. Tanzania for example subscribed to the MDFAL of 2002 in 2008 and remained idle until March 2019 when it established the LII of its own which is known as the Tanzania Legal Information Institute (the TANZLII). ${ }^{5}$ Second, discussion and drafting of the MDFAL of 2002 principles and rules involved only few FALM representatives; hardly seven of them. These representatives who were involved in the preparation of the MDFAL of 2002 were committing atrocities of their own upon other nation globally. In addition, everything in the MDFAL of 2002 is set in singular, nothing is in collective. This article does not suggest that collective approach would have necessarily avoided subsequent weakness of the MDFAL of 2002. However, at the very least, it would have been a more exact repudiation of the MDFAL of 2002 bestiality and made eventual contribution to enforceability of the Right to Access Legal Information Convention (RALIC) for that and as the MDFAL of 2002 as it is, its realization is a mere wishful thinking of the FALM.

\section{Conclusion}

The year 2020 marks the $18^{\text {th }}$ anniversary of the MDFAL of 2002. This anniversary can be celebrated for gigantic achievements brought about in struggles for realization of the right to access legal information since the drafting of this landmark document. The MDFAL of 2002 is beyond doubt a great inspirational document, a remarkable achievement, a worldwide referential document and the one with the highest world obligation. Although the MDFAL of 2002 principles have not been expressly referred to in international and regional legal instruments, its presence stirs up consciousness of countries to look at a possibility of implementation. Besides, its principles have been solemnly recognized as essential as there are regional and national LIIs as the pillars of the FALM for enforcement of the MDFAL of 2002 principles. However, despite numerous achievements, realization and enforcement of the right to access legal information has remained largely difficult. At the same time recognition of the MDFAL of 2002 as international legal instrument binding on nations remains unreality. The notion used above to describe the contributions of the MDFAL of 2002 towards realization of the right to access legal information remains a plight of the FALM activists. This is so because concerted efforts by various actors on access to legal information campaigns produce relatively mixed outcome. It is difficult to blame anyone. It cannot be argued that the difficult is because of recalcitrant Governments which do not enact specific laws for the right

\footnotetext{
${ }^{1}$ The UN has only 14 specialized agencies which are the ILO, the FAO, the UNESCO, the UNICEF, the WHO, the ICAO, the UPU, the ITU, the WMO, the IMO, the WIPO, the IFAD, the UNDIO, the UNWTO, and one related agency IAEA. The FALM, the LII and the MDFAL of 2002 are not among them

${ }^{2}$ See opening statement on the MDFAL of 2002 itself

${ }^{3}$ See for example drafting of ICCPR of 1966 which involved several UN Commissions and reports of Rapportours

${ }^{4}$ List of the legal information institutes representatives participated in drafting of the MDFAL of 2002 is available at page 2 of the MDFAL of 2002 itself

${ }^{5}$ Ndamungu, O. I, op cit, p. 15
} 
to access legal information. This is not so because the Governments have no obligation to enforce the right to access legal information as the MDFAL of 2002 is not in the realm of international law. The developed countries cannot be said to be part of the problem. This is because the USA, being one of the developed countries in the world has benevolently put the principles of the MDFAL of 2002 in legal footing by enacting the UELMA of 2011. The problem therefore is largely with the FALM activists who have ignorantly refused to put the MDFAL of 2002 in the realm of international law. They mostly seem to expect the implementation and enforcement of the principles of the MDFAL of 2002 to be achieved through adherence to the customary international norm of observation of treaties in good faith. This norm is known as pacta sunt servanda principle as it is provided by Article 26 of the Vienna Convention on the Law of Treaties of 1969. It is argued that the pacta sunt servanda principle is not meaningful and relevant to all states and all institutions in states. As a result the realization of the right to access legal information through the MDFAL of 2002 is a failure. The failure is contributed largely by inborn weaknesses of the MDFAL of 2002 itself. Thus, the MDFAL of 2002 is a weak reed to learn on for realization of the right to access legal information.

\section{REFERENCES}

Akintunde, S, E, (2017), A Brief Overview of Legal Informatics, Institute of Legal Informatics, Hanover

Alston, P and Quinn, G., (2007), "The Nature and Scope of State Parties' Obligations in the International Covenant on ESCR," Human Rights Quarterly Law Journal,

Arora, R., (1993), Information Source: Concepts and Need for Information, Library Information Science

Aiyar, R., (2005), Advanced Law Lexicon, the Encyclopedic Law Dictionary with Legal Maxim,

Latin Terms and Words and Phrases, Vol 2, D I, Wadhwa and Compnay Nagpur, New Delhi

Bing, J, (2000), The Policies of Legal Information Service: A Perspective of Three Decades,

Bing, J and Trygve, H, (1975), Legal Decisions and Information Systems, Scandinavian University Press, Oslo

Bygrave, L, Yules (2003), Oslo: Institutt for rettinformatik/Norwegian Research Center for Computers and Law

Capurro, R., (2003), "The Concept of Information," Annual Review of Information Science and Technology, Vol. 37, Hochschule der Medien, Cronin

Daniel, P., (2004), Open Access to Law in Developing Countries, Online Journal of ICT, Vol. 9, No. 12

Danner, R.A., (2010), The IALL International Handbook of Legal Information Management

Dertouzo, M.L and J. Moses, (Eds), (1979), The Computer Age: A Twenty-Year View, MA: MIT Press, Cambridge Eide, A., (1989), "Realization of Social and Economic Rights and the Minimum Threshold Approach," Human Rights Law Journal

Garvin, P,(Ed), (2010), Government Information Management in the Twenty-First Century, Butterworth, London

Greenleaf, G., (2010), "The Global Development of Free Access to Legal Informatics," The European Journal of Law and Technology, Vol. I, Issue 1, Zaragoza University Press, Zaragoza

Greenleaf, G., (2010), The Global Development of Free Access to Legal Informatics, LEFIS Series, University of Zaragoza Press, Zaragoza

Greenleaf, G, et al, (2013), "The Meaning of Free Access to Legal Information: A Twenty Year Evolution," Journal of Open Access to Law, Issue 1

Kondos, G.R., (1973), 'Introduction to JURIS,' A Paper Presented in Abidjan World Conference on World Peace Through Law, Abidjan

Lloyd, J.T., (2000), Information Technology Law, $3^{\text {rd }}$ Edition, Butterworth, London, Mambi, A.J., (2010), ICT Law Book: A Sourcebook for Information and Communication Technologies Law in Tanzania and East Africa, Mkuki and Nyota, Dar es Salaam

Martini, M., (2014), Right to Information Law: Impact and Implementation, Transparency International, No. 10

Mitee, L.E, (2017), The Right of Public Access to Legal Information: A Proposal for Its Universal Recognition as a Human Right, European Journal of Law and Technology, Vol. 8, No.3

Ndamungu, O.I., (2020), Legal and Policy Approaches Toward Realization of the Right to Access Legal Information, International Journal of Research of Sharia, Muamalat and Islam, Vol.2, No. 5

Neuman, L, (2009), Enforcement Models Content and Context, Access to Information Working Paper Series Washington DC

Omar, J., (1990), Regulating Broadcasting in Tanzania, A Thesis for Diploma in Journalism, Tanzania School of Journalism, Dar es Salaam

Paliwala, A (Ed), (2010), “A History of Legal Information,” LEFIS Series, University of Zaragoza Press

Paliwala, A., (Ed), (2010), “A History of Legal Informatics, ” LEFIS Series 9, Prensas Universitarias de Zaragoza, Zaragoza

Singh, L.P. and Majumdar, P.K., (2005), Judicial Dictionary, Orient Publishing Company, New Delhi

Singh, R, et al, (Eds), (2012), Access to Legal Information and Research in Digital Age, National Law University Press, Delhi

Sturmer, M., (2008), The Media History in Tanzania, Ndanda Mission Press, Mtwara 